\title{
Mathematical modeling of dehydration of 'Fuji' and 'Gala' apples slices using infrared
}

\author{
Modelagem matemática da desidratação de fatias de maçã 'Fuji' e 'Gala’ por infravermelho
}

\author{
Emílio de Souza SANTOS ${ }^{1 \star}$, Paulo Cesar CORRÊA ${ }^{1}$, Fernanda Machado BAPTESTINI ${ }^{1}$, \\ Fernando Mendes BOTELHO ${ }^{1}$, Felipe Elia de Almeida MAGALHÃES ${ }^{1}$
}

\begin{abstract}
The objective of this work was to determine and model the infrared dehydration curves of apple slices - Fuji and Gala varieties. The slices were dehydrated until constant mass, in a prototype dryer with infrared heating source. The applied temperatures ranged from 50 to $100{ }^{\circ} \mathrm{C}$. Due to the physical characteristics of the product, the dehydration curve was divided in two periods, constant and falling, separated by the critical moisture content. A linear model was used to describe the constant dehydration period. Empirical models traditionally used to model the drying behavior of agricultural products were fitted to the experimental data of the falling dehydration period. Critical moisture contents of 2.811 and $3.103 \mathrm{~kg}_{\mathrm{w}} \mathrm{kg}_{\mathrm{s}}^{-1}$ were observed for the Fuji and Gala varieties, respectively. Based on the results, it was concluded that the constant dehydration rates presented a direct relationship with the temperature; thus, it was possible to fit a model that describes the moisture content variation in function of time and temperature. Among the tested models, which describe the falling dehydration period, the model proposed by Midilli presented the best fit for all studied conditions.
\end{abstract}

Keywords: Malus domestica; constant period; falling period; critical moisture content; Midilli.

\begin{abstract}
Resumo
O presente trabalho foi realizado com o objetivo de determinar e modelar as curvas de desidratação por infravermelho de fatias de maçã das cultivares Fuji e Gala. As fatias foram desidratadas até atingir massa constante, em um secador protótipo com fonte de aquecimento por infravermelho, utilizando-se uma faixa de temperatura de 50 a $100{ }^{\circ} \mathrm{C}$. Devido às características físicas do produto, a desidratação foi dividida em dois períodos, constante e decrescente, separados por um teor de água crítico. Para a modelagem do período de desidratação constante, utilizou-se um modelo linear. Aos dados experimentais do período decrescente de desidratação, foram ajustados modelos empíricos tradicionalmente utilizados para modelagem do processo de secagem de produtos agrícolas. Foi obtido um teor de água crítico de 2,811 e 3,103 $\mathrm{kgw} \mathrm{kgs}^{-1}$ para as cultivares Fuji e Gala, respectivamente. Pelos resultados obtidos, concluiu-se que a taxa de desidratação constante apresentou uma relação direta com a temperatura, possibilitando ajustar um modelo que descreve a variação do teor de água em função do tempo e da temperatura. Dentre os modelos utilizados para descrever o período decrescente de desidratação, o proposto por Midilli foi o que melhor se ajustou aos dados experimentais, para todas as condições estudadas.

Palavras-chave: Malus domestica; período constante; período decrescente; teor de água crítico; Midilli.
\end{abstract}

\section{Introduction}

Apple, like the majority of fruits and vegetables, has a limited shelf life depending on the environmental conditions where it is exposed or stored. Due to its seasonal production, apple needs to be stored in order to regulate the offer during the whole year. Storage under refrigeration and controlled atmosphere is the most common method to preserve quality and minimize post-harvest losses (BRACKMANN et al., 2003).

Another alternative technically and economically viable to store apple for a long period of time is dehydration. The decrease of the moisture content of the product reduces the biological and chemical activities that occur during storage (CORRÊA et al., 2007). New potential methods to dehydrate biological products, which are more efficient energetically and also provide a high quality of finished products, like the use of microwave and infrared, have been investigated by several researchers (UMESH HEBBAR; RASTOGI, 2001; NOWAK; LEWICKI, 2004; TOĞRUL, 2005; SWASDISEVI et al., 2009).
Infrared heating offers many advantages over convective dehydration systems under similar conditions. Shorter time process, higher energy efficiency, and compact and automated equipment with high degree of control (NOWAK; LEWICKI, 2004) are some of the advantages. When infrared radiation is used to heat or dehydrate moist materials, the radiation impinges the exposed material, penetrates it and the energy of radiation is converted into heat (UMESH HEBBAR; RASTOGI, 2001). The penetration depth depends on the product properties and on the radiation wavelength. When biological products are radiated by infrared, they are heated intensely and the temperature gradient in the material reduces in a short time (TOĞRUL, 2005). As a result, infrared dehydration presents a high heat transfer rate when compared to conventional systems and a uniform heating of the product, providing high quality of finished products.

In studies of new technologies and systems of dehydration, the process simulation is important to the development,

${ }^{1}$ Centro Nacional de Treinamento em Armazenagem, Campus da Universidade Federal de Viçosa, s/n, CEP 36570-000,Viçosa, MG, Brasil, e-mail: emilio_ss@hotmail.com ${ }^{*}$ Corresponding author 
optimization, design and determination of the commercial viability for the new equipment. For this reason, several mathematical models have been proposed to analyze the dehydration process of hygroscopic products.

Basically, there are two types of models: theoretical models that are based on the understanding on the fundamental phenomena and mechanisms; and the empirical models that are based on the mathematical behavior of experimental data. The empiric models, although not based on theories, are generally simpler and easier to apply (BROOKER et al., 1992).

However, the traditional empirical models proposed to be fitted to dehydration processes only represent the falling dehydration period, due to the mathematical behavior of these models. Hygroscopic products, which have high moisture content, behave as if a thin water layer covers the product surface. When these products are dried at constant air conditions, the water layer evaporates at a constant rate, and water is immediately replaced by the product (BROOKER et al., 1992). This phenomenon happens because the internal resistance to the water transport is less than the resistance to evaporate the surface water (CORREA et al., 2007). The period in which the internal resistance starts to become higher than the external resistance is known as constant dehydration period. The moisture content which is the transition between the constant and the falling dehydration periods is called critical moisture content.

This work was carried out considering the necessity to acquire technical information that could aid producers and engineers to perform the suitable processing of apple and the development of new technologies for this purpose. It aimed to study the infrared dehydration process of apple slices of Fuji and Gala varieties and to model the dehydration curves during the constant and the falling rate periods.

\section{Materials and methods}

This work carried out at the Physical Properties and Quality Analysis of Agricultural Products - National Center for Storage Training (CENTREINAR), at the Federal University of Viçosa, State of Minas Gerais, Brazil.

Fresh 'Fuji' and 'Gala' apples, with initial average moisture content of 5.967 and $7.064 \mathrm{~kg}_{\mathrm{w}} \mathrm{kg}_{\mathrm{s}}^{-1}$ ( $\mathrm{kg}$ of water per $\mathrm{kg}$ of dry solids), respectively, were purchased at local markets and stored in a BOD chamber under controlled temperature $\left(+5 \pm 1^{\circ} \mathrm{C}\right)$. Samples were sliced in their transverse axes with approximate thickness of $1.2 \mathrm{~mm}$.

The samples were dehydrated under the temperatures of $50,60,70,80,90$ and $100{ }^{\circ} \mathrm{C}$ using an infrared prototype dryer which is equipped with a $0.001 \mathrm{~g}$ resolution coupled scale and an automatic data acquisition system. The heat source transmits infrared radiation in wavelengths between 0.75 and $1 \mu \mathrm{m}$. The distance between the radiation source and the apple slices was fixed in $60 \mathrm{~mm}$. The dryer was previously warmed, and the samples were dehydrated until the mass variation reached a lower than $0.002 \mathrm{~g}$ value.

The critical moisture content was estimated through the method of tangent at origin, described by Derdour (1998 apud DISSA et al., 2010). This method consists in plotting the constant rate and the tangent at the origin of the curve representing the dehydrate rate according to the product moisture content. The critical point can be seen at the point of intersection between the two lines. Due to the complexity of the curve and the lack of an analytic method to determine the critical moisture content, the method was performed graphically, considering the constant rate as an average value of the curve last quartile.

Moisture content variation during the constant dehydration period was linearly described in function of time, assuming a mean initial moisture content, showed by Equation 1. The constant dehydration rate, for each variety and temperature, was obtained fitting Equation 1 to the experimental data using the least squares method:

$U_{t}=\bar{U}_{0}-c t$

where: $U_{t}$ is the moisture content at time, $\mathrm{kg}_{\mathrm{w}} \mathrm{kg}_{\mathrm{s}}^{-1} ; \bar{U}_{0}$ is the mean initial moisture content, $\mathrm{kg}_{\mathrm{w}} \mathrm{kg}_{\mathrm{s}}{ }^{-1} ; \mathrm{t}$ is the dehydration time, min.; and $\mathrm{c}$ is the constant dehydration rate, $\mathrm{kg}_{\mathrm{w}} \mathrm{kg}_{\mathrm{s}}^{-1} / \mathrm{min}$.

Mathematical models (Table 1) traditionally used to describe the dehydration kinetic in a thin layer of biological products were fitted to the curves of the falling dehydration

Table 1. Mathematical models used to describe the dehydration kinetic in a thin layer of biological product.

\begin{tabular}{lcc}
\hline \multicolumn{1}{c}{ Name } & Model equation & References \\
\hline Diffusion approach & $R U=a \exp (-k t)+(1-a) \exp (-k b t)$ & Yaldiz and Ertekin (2001) \\
Henderson and Pabis & $R U=a \exp (-k t)$ & Westerman et al. (1973) \\
Logarithmic & $R U=a \exp (-k t)+b$ & Yagcioglu et al. (1999) \\
Midilli & $R U=a \exp \left(-k t^{n}\right)-b t$ & Midilli et al. (2002) \\
Page & $R U=\exp \left(-k t^{n}\right)$ & Zhang and Litchfield (1991) \\
Thompson & $R U=\exp \left\{\frac{\left[-a-\left(a^{2}+4 b t\right)^{0,5}\right]}{2 b}\right\}$ & Brooker et al. (1992) \\
& $R U=a \exp (-k t)+b \exp (-g t)$ & (3) \\
Two term & $R U=a \exp (-k t)+(1-a) \exp (-g t)$ & Henderson (1974) \\
Verma & Verma et al. (1985)
\end{tabular}

where: $\mathrm{RU}$ is the moisture ratio, dimensionless; $\mathrm{k}$ is the dehydration constant, $\min ^{-1}$; and $\mathrm{a}, \mathrm{b}, \mathrm{g}, \mathrm{n}$ are empirical coefficients of the models 
period. The models were fitted using the non-linear regression by the Gauss Newton method, using STATISTICA $8.0^{\circ}$ software.

In processes using infrared as a heat source, the product is completed dehydrated (TOĞRUL, 2006); therefore, the equilibrium moisture content is equals zero. For this reason, the moisture ratio was calculated by Equation 10:

$R U=\frac{U_{t}}{U_{c r}}$

where: $\mathrm{U}_{\mathrm{cr}}$ is the critical moisture content, $\mathrm{kg}_{\mathrm{w}} \mathrm{kg}_{\mathrm{s}}{ }^{-1}$.

The best model describing the falling dehydration period was chosen as the one with the highest determination coefficient $\left(\mathrm{R}^{2}\right)$, the lowest relative standard deviation (RSD) and standard error (SE) (PALIPANE; DRISCOLL, 1994; MADAMBA et al., 1996; MOHAPATRA; RAO, 2005). The relative standard deviation and standard error, for each model and temperature, were calculated using the followed Equations 11 and 12:

$$
\begin{aligned}
& R S D=\frac{100}{n} \sum \frac{|Y-\hat{Y}|}{Y} \\
& S E=\sqrt{\frac{\sum(Y-\hat{Y})^{2}}{n_{d}-n_{p}}}
\end{aligned}
$$

where: $\mathrm{Y}$ is the experimental data; $\hat{\mathrm{Y}}$ is the predicted data; $\mathrm{n}_{\mathrm{d}}$ is the number of experimental data; and $n_{p}$ is the number of parameters of the model.

After the selection of the model for representing the dehydration periods of each variety, the models identity technique, described by Regazzi (2003), was applied to the selected models. This statistical technique consists in analyzing the equivalence between the adjusted models by a hypothesis test. The nullity hypothesis is that each model coefficient is equal for both samples; in other words, there is an equivalent model that represents the phenomena for both samples. The alternative hypothesis is that there is at least one coefficient inequality.

The hypothesis test supposes two complete models that describe the phenomena for both of samples, one with all coefficients restricted $(\mathrm{w})$ and the other without restriction $(\Omega)$. These models were created using the dummy variable (D): $D i=1$ if the $y \mathrm{ij}$ observation belongs to the $i$ group; and $D \mathrm{i}=0$ on the opposite case (REGAZZI, 2003). An example of these complete models, for Page model, is given by Equations 13 and 14:

$$
\begin{aligned}
& \Omega_{i j}=D_{1}\left[\exp \left(-k_{1} t^{n_{1}}\right)\right]+D_{2}\left[\exp \left(-k_{2} t^{n_{2}}\right)\right] \\
& w_{i j}=D_{1}\left[\exp \left(-k t^{n}\right)\right]+D_{2}\left[\exp \left(-k t^{n}\right)\right]
\end{aligned}
$$

The decision rule is based on the chi-square test $\left(\chi^{2}\right)$, comparing the calculated value, obtained through Equation 15, with the tabled value, which is a function of the significance level and the degrees of freedom of the test, obtained by Equation 16 . If the calculated chi-square value is greater than the tabled one, the nullity hypothesis is rejected. $\chi_{\text {calc }}^{2}=-n_{d} \ln \left(\frac{S D S_{\Omega}}{S D S_{w}}\right)$

$D O F=n_{\Omega}-n_{w}$

where: $\mathrm{SDS}_{\Omega}$ is the square deviation sum of the complete model without restriction; $\mathrm{SDS}_{\mathrm{w}}$ is the square deviation sum of the complete model restricted; DOF is the degree of freedom; $n_{\Omega}$ is the number of parameters of the complete model without restriction; and $n_{w}$ is the number of parameters of the complete model restricted.

\section{Results and discussion}

The critical moisture content obtained, for both varieties ranged between 2.400 and $3.750 \mathrm{~kg}_{\mathrm{w}} \mathrm{kg}_{\mathrm{s}}{ }^{-1}$, with a mean value of $2.811 \pm 0.451 \mathrm{~kg}_{\mathrm{w}} \mathrm{kg}_{\mathrm{s}}^{-1}$ and $3.103 \pm 0.570 \mathrm{~kg}_{\mathrm{w}} \mathrm{kg}_{\mathrm{s}}{ }^{-1}$ for Fuji and Gala varieties, respectively. The mean value was taken to simplify the modeling process. Dissa et al. (2010) obtained critical moisture content values of $1.444,1.607$ and $1.765 \mathrm{~kg}_{\mathrm{w}} \mathrm{kg}_{\mathrm{s}}^{-1}$ for the convective drying of spirulina, for a cylinder form with diameters of 3, 4 and $6 \mathrm{~mm}$, respectively. Desmorieux et al. (2008) reported critical moisture content values varying from 4.100 to $6.800 \mathrm{~kg}_{\mathrm{w}} \mathrm{kg}_{\mathrm{s}}^{-1}$ for the convective drying of parallelepiped pieces of mango, at different air conditions.

Figure 1 shows the experimental data of the constant dehydration rate of each variety and the predicted equations by linear regression, which relates dehydration rate with temperature.

It can be seen from Figure 1 that the dehydration rate increased as the temperature increased, for both varieties. This behavior occurs due to the increase in the gradient of vapor pressure between the water layer surface and the air. The determination coefficient for both adjustments was greater than 90\%, showing an acceptable fitting (MADAMBA et al., 1996). Brooker et al. (1992) reported that the constant dehydration

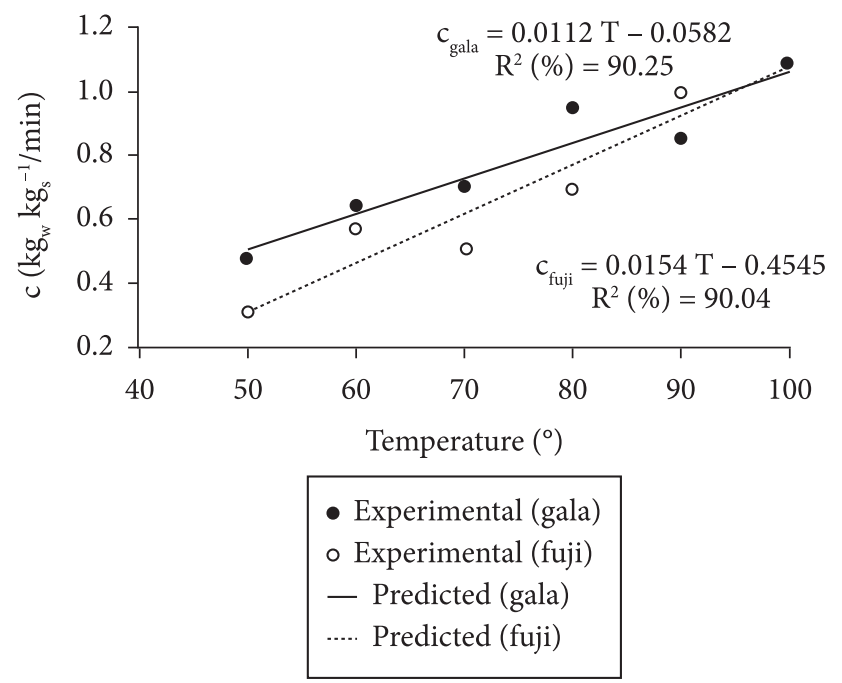

Figure 1. Experimental and predicted data of dehydration rate during the constant dehydration period in function of temperature. 
rate can only be precisely calculated if both the behavior of the specific surface area and the mass transfer coefficient are known. Due to some phenomena such as shrinkage and convection, these values are difficult to be obtained with accuracy.

In order to create a model that describes the moisture content variation in function of time and temperature, the constant dehydration rate and the mean initial moisture content were substituted in Equation 1, by the adjusted linear model and the obtained values, respectively. Table 2 shows the equations that describe the constant dehydration period in function of temperature and dehydration time, as well as the relative standard deviation (RSD) between the proposed models and the experimental data. Both equations presented values of relative standard deviation lower than $10 \%$, indicating satisfactory representation of the studied phenomena (CHEN; MOREY, 1989; MADAMBA et al., 1996; MOHAPATRA; RAO, 2005).

Analyzing the hypothesis that each model coefficient is equal for both samples, it was obtained a calculated chi-square value of 22.885 - greater than the tabled value of 5.991. Degrees of freedom of the test equals 2 and significance level of 5\% were supposed. As a result, the hypothesis of an equivalent model that describes the constant dehydration period for both varieties was rejected.

Figure 2 shows the correspondence between the experimental and predicted data of the constant dehydration period for each variety. The suitable description of the constant dehydration period by the models can be seen.

After the analysis of the statistical parameters of each adjusted model to the falling dehydration period data, it was observed that the Henderson and Pabis, Logarithm, Midilli, Page, Two Terms and Verma models presented values of relative standard deviation lower than $10 \%$ and determination coefficient greater than $98 \%$, indicating, in agreement with Mohapatra and Rao (2005), satisfactory representation of the studied phenomena.

Among all the suitable models, the Midilli's model was selected to represent the phenomena, since it presented the lowest values of SE and RSD and the greatest values of $\mathrm{R}^{2}$ for all studied conditions. The Midilli's model was recommended to describe the dehydration of various products: by Toğrul (2005) for apple slices using infrared in a temperature range from 50 to $80{ }^{\circ} \mathrm{C}$; by Martinazzo et al. (2007) for leaves of lemon grass; by Corrêa et al. (2007) for beans; and by Silva et al. (2008) for tamarind pulp.

Table 3 shows the coefficients of the Midilli's model obtained through the Gauss Newton method of non-linear regression, to each dehydration condition and variety studied.

As shown on Table 3, it was verified that all obtained coefficients varied in function of temperature. Hence, linear and exponential models were fitted, using the least squares method, in order to describe the variation of Midilli's model coefficients in function of temperature (MADAMBA et al., 1996). Table 4 shows the regression equations adjusted to the coefficients of the Midilli's model in function of temperature and their respective determination coefficients.
Table 2. Equations that describe the constant dehydration period for each variety.

\begin{tabular}{cccc}
\hline Variety & Equation & RSD (\%) & Equation \\
\hline Fuji & $U_{t}=5.967-(0.0154 T-0.4545) t$ & 8.30 & $(17)$ \\
Gala & $U_{t}=7.064-(0.0112 T-0.0582) t$ & 9.29 & $(18)$ \\
\hline
\end{tabular}

Where: $\mathrm{T}$ is temperature, ${ }^{\circ} \mathrm{C}$.
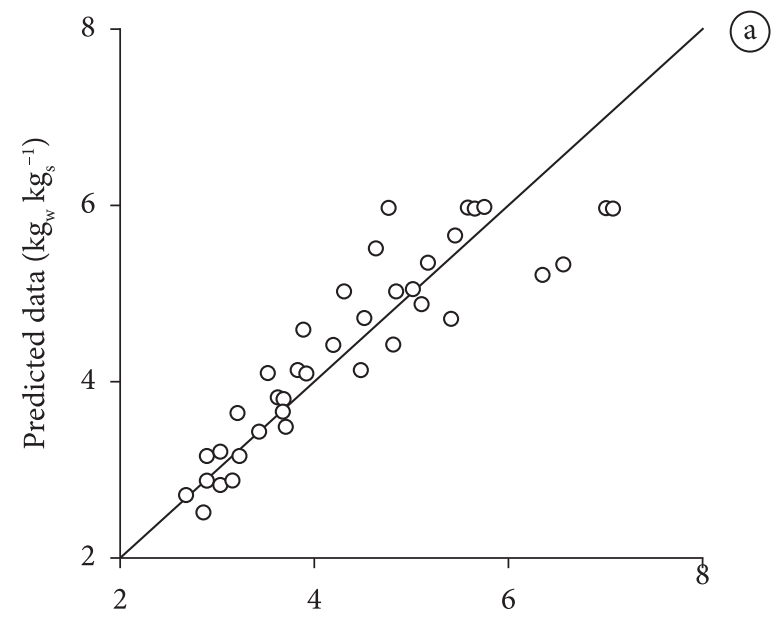

Experimental data $\left(\mathrm{kg}_{\mathrm{w}} \mathrm{kg}_{\mathrm{s}}^{-1}\right)$

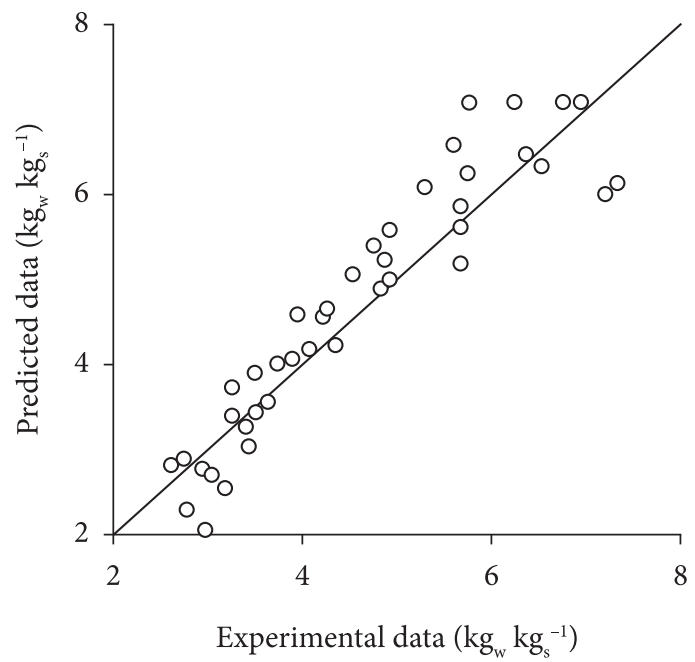

(b)

Figure 2. Correspondence between the experimental and predicted data of the constant dehydration period of: a) 'Fuji', and b) 'Gala' varieties.

Analyzing the hypothesis of an equivalent model, for Midilli's model with its coefficients described in function of temperature, it was obtained a calculated chi-square value of 261.726 - greater than the tabled value of 15.507 . It was considered the degrees of freedom of the test equal to eight and significance level of 5\%. As a result, the hypothesis of an equivalent model that describes the falling dehydration period for both varieties was rejected. The conclusion of these analysis are that each studied variety presents a different behavior when submitted to the same dehydration conditions, due to the 
Table 3. Coefficients of the Midilli model to each dehydration temperature and variety studied.

\begin{tabular}{|c|c|c|c|c|c|c|c|c|}
\hline \multirow[t]{2}{*}{$\mathrm{T}\left({ }^{\circ} \mathrm{C}\right)$} & \multicolumn{8}{|c|}{ Coefficients } \\
\hline & \multicolumn{4}{|c|}{ Fuji } & \multicolumn{4}{|c|}{ Gala } \\
\hline 50 & 1.0737 & 0.0639 & 0.8712 & 0.2170 & 1.0772 & 0.0686 & 0.8550 & 0.2690 \\
\hline 70 & 1.1871 & 0.1669 & 0.8331 & 0.7690 & 1.1485 & 0.1352 & 0.8357 & 0.7300 \\
\hline 80 & 1.2679 & 0.2282 & 0.8293 & 1.0540 & 1.1977 & 0.1782 & 0.8370 & 1.6060 \\
\hline
\end{tabular}

Table 4. Dependency equation between the coefficients of Midilli model and dehydration temperature.

\begin{tabular}{|c|c|c|}
\hline \multicolumn{3}{|l|}{ Fuji } \\
\hline Equation & $\mathrm{R}^{2}(\%)$ & Equations \\
\hline$\hat{a}=0.00546 T+0.79411$ & 94.78 & (19) \\
\hline$\hat{k}=0.00419 T-0.14111$ & 96.41 & $(20)$ \\
\hline$\hat{n}=-0.00138 T+0.94011$ & 91.43 & (21) \\
\hline$\hat{b}=2.92610^{-5} \exp \left(4.13710^{-2} T\right)$ & 83.63 & $(22)$ \\
\hline \multicolumn{3}{|l|}{ Gala } \\
\hline Equation & $\mathrm{R}^{2}(\%)$ & Equations \\
\hline$\hat{a}=0.00491 T+0.82221$ & 94.86 & (23) \\
\hline$\hat{k}=0.00412 T-0.14107$ & 96.40 & (24) \\
\hline$\hat{n}=-0.00120 T+0.91585$ & 98.50 & (25) \\
\hline$\hat{b}=3.71210^{-5} \exp \left(4.73010^{-2} T\right)$ & 92.92 & (26) \\
\hline
\end{tabular}

different physicochemical properties inherent to each variety. Some examples are: the initial moisture content which was observed being different for each variety; the tissue physical structure, which influences the water diffusion phenomena; and the chemical constitution, which has influence upon the hygroscopic behavior.

Figure 3 shows the correspondence between the experimental and predicted data of the Midilli's model, with its coefficients described in function of temperature, for each variety.

It can be seen the suitable description of the falling dehydration period by the models. The relative standard deviation of each model was 9.96 and $7.72 \%$ for the dehydration of 'Fuji' and 'Gala' varieties, respectively. Both equations presented values of relative standard deviation lower than $10 \%$, indicating satisfactory representation of the studied phenomena (CHEN; MOREY, 1989; MADAMBA et al., 1996; MOHAPATRA; RAO, 2005).

\section{Conclusions}

The mean value of critical moisture contents obtained were $2.811 \pm 0,451 \mathrm{~kg}_{\mathrm{w}} \mathrm{kg}_{\mathrm{s}}^{-1}$ and $3.103 \pm 0,570 \mathrm{~kg}_{\mathrm{w}} \mathrm{kg}_{\mathrm{s}}{ }^{-1}$ for Fuji and Gala varieties, respectively. The constant dehydration rate increased linearly with temperature increase; thus, the constant

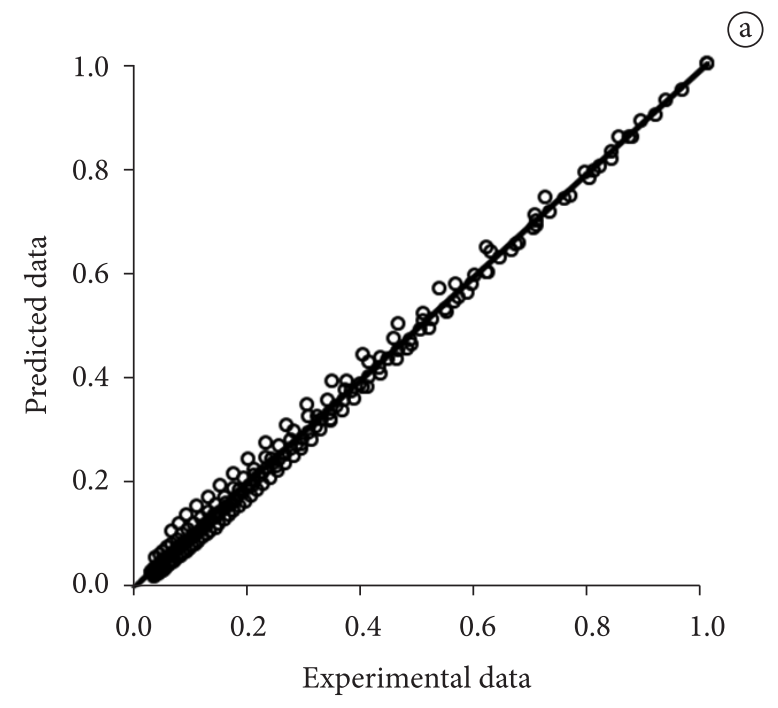

(b)

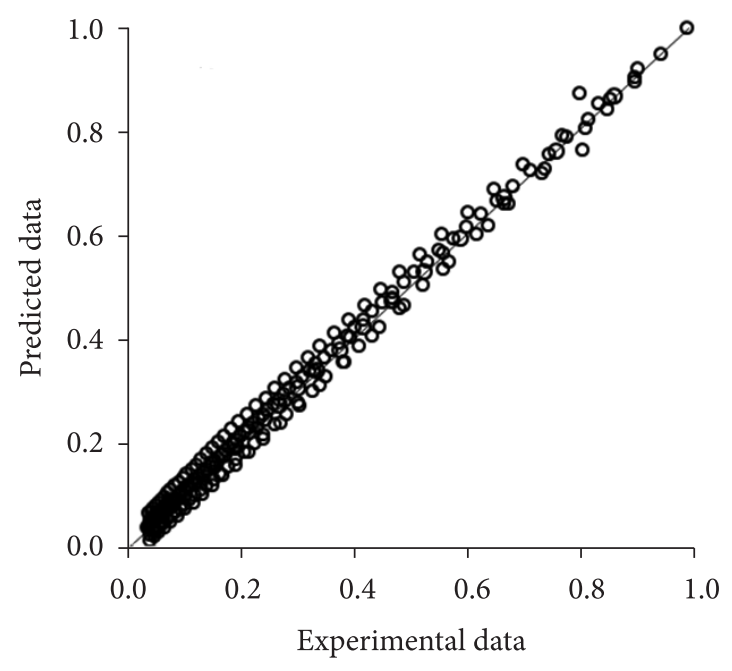

Figure 3. Correspondence between the experimental and predicted data of the falling dehydration period of: a) 'Fuji', and b) 'Gala' varieties.

dehydration period could be represented by a model in function of time and temperature of processing. Midilli's model was the model that showed the best fit to the falling dehydration period data, and the variation of its coefficients could be described by linear and exponential models, in function of temperature; 
therefore, the falling dehydration period could be represented by a model in function of time and temperature of processing. Using the models identity technique, it was verified that an equivalent mathematical model, common to both varieties and able to describe each dehydration period, cannot be representative.

\section{Acknowledgements}

The authors are grateful to 'CNPq' for the financial support, essential to this work.

\section{References}

BRACKMANN, A. et al. Armazenamento de maçã ‘Gala’ em atmosfera controlada com remoção de etileno. Revista Ciência Rural, v. 33, n. 4, p. 647-650, 2003.

BROOKER, D. B.; BAKKER-ARKEMA, F. W.; HALL, C. W. Drying and storage of grains and oilseeds. New York: Van Nostrand Reinhold, 1992.

CHEN, C.; MOREY, R. V. Comparison of four ERH/EMC equations. Transactions of ASAE, v. 32, p. 983-990, 1989.

CORRÊA, P. C. et al. Modelagem matemática para a descrição do processo de secagem do feijão (Phaseolus vulgaris L.) em camadas delgadas. Engenharia Agrícola, v. 27, n. 2, p. 501-510, 2007.

DERDOUR, L., 1998. Contribution au concept de la courbe caractéristique de séchage (C.C.S). Application au séchage de produits de type plâtre. 1998. Tese (Doctorat)-Université Claude Bernard de Lyon, Lyon, 1998.

DESMORIEUX, H.; DIALlO, C.; COUlibAlY, Y. Operation simulation of a convective and semi-industrial mango dryer. Journal of Food Engineering, v. 89, p. 119-127, 2008. http://dx.doi. org/10.1016/j.jfoodeng.2008.04.007

DISSA, A. O. et al. Shrinkage, porosity and density behavior during convective drying of spirulina. Journal of Food Engineering, v. 97, p. 410-418, 2010. http://dx.doi.org/10.1016/j.jfoodeng.2009.10.036

HENDERSON, S. M. Progress in developing the thin layer drying equation. Transaction of ASAE, v. 17, p. 1167-1172, 1974.

MADAMBA, P. S.; DRISCOLL, R. H.; BUCKLE, K. A. Thin-layer drying characteristics of garlic slices. Journal of Food Engineering, v. 29, p. 75-97, 1996. http://dx.doi.org/10.1016/0260-8774(95)00062-3

MARTINAZZO, A. P. et al. Análise e descrição matemática da cinética de secagem de folhas de capim-limão. Revista Brasileira de Engenharia Agrícola e Ambiental, v. 11, n. 3, p. 301-306, 2007.

MIDILLI, A.; KUCUK, H.; YAPAR, Z. A new model for single layer drying. Drying Technology, v. 20, n. 7, p. 1503-1513, 2002. http:// dx.doi.org/10.1081/DRT-120005864
MOHAPATRA, D.; RAO, P. S. A thin layer drying model of parboiled wheat. Journal of Food Engineering, v. 66, p. 513-518, 2005. http:// dx.doi.org/10.1016/j.jfoodeng.2004.04.023

NOWAK, D.; LEWICKI, P. P. Infrared drying of apple slices. Innovative Food Science and Emerging Technologies, v. 5, p. 353-360, 2004. http://dx.doi.org/10.1016/j.ifset.2004.03.003

PALIPANE, K. B.; DRISCOLL, R. H. Thin-layer drying behavior of Macadamia in-shell nuts and kernels. Journal of Food Engineering, v. 23, p. 129-144, 1994. http://dx.doi.org/10.1016/02608774(94)90082-5

REGAZZI, A. J. Teste para verificar a igualdade de parâmetros e a identidade de modelos de regressão não-linear. Revista Ceres, v. 50 , n. 287 , p. 9-26, 2003

SILVA, A. S. et al. Desidratação da polpa de tamarindo pelo método de camada de espuma. Ciência e Agrotecnologia, v. 32, n. 6, p. 1899-1905, 2008.

SWASDISEVI T. et al. Mathematical modeling of combined farinfrared and vacuum drying banana slice. Journal of Food Engineering, v. 92, p. 100-105, 2009. http://dx.doi.org/10.1016/j. jfoodeng.2008.10.030

TOĞRUL, H. Simple modeling of infrared drying of fresh apple slices. Journal of Food Engineering, v. 71, p. 311-323, 2005. http://dx.doi. org/10.1016/j.jfoodeng.2005.03.031

TOĞRUL, H. Suitable drying model for infrared drying of carrot. Journal of Food Engineering, v. 77, p. 610-619, 2006. http://dx.doi. org/10.1016/j.jfoodeng.2005.07.020

UMESH HEBBAR, H.; RASTOGI, N. K. Mass transfer during infrared drying of cashew kernel. Journal of Food Engineering, n. 47, p. 1-5, 2001. http://dx.doi.org/10.1016/S0260-8774(00)00088-1

VERMA, L. R. et al. Effects of drying air parameters on rice drying models. Transaction of ASAE, v. 28, p. 296-301, 1985.

WESTERMAN, P. W.; WHITE, G. M.; ROSS, I. J. Relative humidity effect on the high temperature drying of shelled corn. Transactions of the ASAE, v. 16, p. 1136-1139, 1973.

YAGCIOGLU, A.; DEGIRMENCIOGLU, A.; CAGATAY, F. Drying characteristic of laurel leaves under different conditions. Proceedings of 7 th international congress on agricultural mechanization and energy, p. 565-569, 1999.

YALDIZ, O.; ERTEKIN, C. Thin layer solar drying of some vegetables. Drying Technology, v. 19, p. 583-596, 2001. http://dx.doi. org/10.1081/DRT-100103936

ZHANG, Q.; LITCHFIELD, J. B. An optimisation of intermittent corn drying in a laboratory scale thin layer dryer. Drying Technology, v. 9, p. 383-395, 1991. http://dx.doi.org/10.1080/07373939108916672 